\author{
UNIVERSIDADE DE SÃO PAULO \\ INSTITUTO DE RELAÇÕES INTERNACIONAIS
}

DEBORA RAMIRES PELISSON

Tracing the institutionalization process of informal institutions: the case study of the Chiang Mai Initiative Multilateralization 


\author{
UNIVERSIDADE DE SÃO PAULO \\ INSTITUTO DE RELAÇÕES INTERNACIONAIS
}

DEBORA RAMIRES PELISSON

Rastreando o processo de institucionalização de instituições informais: o estudo de caso da Chiang Mai Initiative Multilateralization 


\section{DEBORA RAMIRES PELISSON}

Tracing the institutionalization process of informal institutions: the case study of the Chiang Mai Initiative Multilateralization

Tese apresentada ao Programa de PósGraduação em Relações Internacionais do Instituto de Relações Internacionais da Universidade de São Paulo, para a obtenção do título de Doutor em Ciências.

Área de Concentração: Relações Internacionais

Linha de Pesquisa: Economia Política Internacional

Orientador(a): $\quad \operatorname{Prof}(\mathbf{a}) . \quad \operatorname{Dr}(\mathbf{a}) . \quad$ Maria Antonieta Del Tedesco Lins

\section{Versão simplificada}

A versão original se encontra disponível na Biblioteca do Instituto de Relações Internacionais.

São Paulo

2020 
Autorizo a reprodução e divulgação total ou parcial deste trabalho, por qualquer meio convencional ou eletrônico, para fins de estudo e pesquisa, desde que citada a fonte.

\section{Catalogação na publicação \\ Seção Técnica de Biblioteca \\ Instituto de Relações Internacionais da Universidade de São Paulo}

Elaborado por Giseli Adornato de Aguiar - CRB-8/6813

Pelisson, Debora Ramires

Tracing the institutionalization process of informal institutions: the case study of the Chiang Mai Initiative Multilateralization / Debora Ramires Pelisson ; orientadora: Maria Antonieta Del Tedesco Lins . -- São Paulo, 2020.

$168 \mathrm{p}$.

Tese (Doutorado) - Instituto de Relações Internacionais. Universidade de São Paulo, São Paulo, 2021.

1. Chiang Mai Initiative Multilateralization 2. Acordos regionais de financiamento 3. Desenho institucional 4. Cooperação financeira 5. Arquitetura financeira internacional. I. Lins, Maria Antonieta Del Tedesco, orient. II. Título.

CDD - 337.1

Responsável: Maria Marta Nascimento - CRB-8/6200 


\section{AGRADECIMENTOS}

Esta tese foi desenvolvida com apoio dos recursos do Conselho Nacional de Desenvolvimento Científico e Tecnológico (CNPq) e do Deutscher Akademischer Austauschdienst (DAAD) que financiaram meus estudos na Universidade de Heidelberg (Ruprecht-Karls-Universität Heidelberg) na Alemanha.

Gostaria de agradecer ao Professor Dr. Prof. Rahul Mukherji, que foi meu orientador durante o estágio no exterior, pela disponibilidade em me receber e pelos ensinamentos, sobretudo, no que concerne à metodologia que, certamente, contribuíram para a minha formação como cientista política.

Meus sinceros agradecimentos à minha orientadora Professora Dra. Maria Antonieta Del Tedeso Lins que me acompanhou na minha jornada acadêmica desde o Mestrado, por seus aconselhamentos e liberdade na condução da pesquisa, por sua confiança, dedicação, comprometimento (sempre lendo e relendo todas as versões do texto, sempre presente e disponível para as reuniões, resposta de e-mails e conversas no celular) e por ter sido fundamental na realização do meu desejo de estudar no exterior.

Agradeço de forma muito especial minha grande companheira e amiga de todas as horas, desabafos, alegrias, discussões, questionamentos, nessa montanha russa de emoções que é o doutorado, Marketa Jerabek. Enfim, conseguimos, chegamos juntas ao final dessa trajetória. Desejo-lhe muito sucesso nas futuras empreitadas acadêmicas e que nossa amizade permaneça.

Registro também um agradecimento aos integrantes da banca do exame de qualificação, Professoras Camila Duran e Adriana Schor, pelas contribuições valiosas ao trabalho.

Por fim, agradeço, com muito carinho, à minha família - pai, mãe, irmã - ao meu noivo Samuel e às minhas amigas da vida - Carolina, Lígia, Flávia Passos, Flávia Diniz, Marcela e Mariana -, que mesmo não compreendendo muito bem o que é fazer um doutorado nem minha pesquisa, sempre me apoiaram, torceram por mim e se alegraram com as minhas conquistas. Amo todos vocês e dedico esta tese a vocês.

Sinto que com a conclusão desta tese, encerro um capítulo importante, uma caminhada acadêmica e uma relação de muito amor e respeito à USP que se iniciou lá na graduação. Vai ser difícil esquecer meu querido número USP, 5869141. Espero sempre voltar em novos contextos e desafios e pode retribuir a excelente formação que essa Universidade me deu. 


\section{Rastreando o processo de institucionalização de instituições informais: o estudo de caso da Chiang Mai Initiative Multilateralization}

\section{Resumo}

O objetivo geral deste trabalho é entender o desenho institucional dos acordos regionais de financiamento (ARFs). O objetivo específico é entender o desenho institucional da Chiang Mai Initiative Mutilateralization (CMIM) que se afasta dos outros casos de ARFs presentes no atual sistema financeiro internacional, no que se refere ao grau de formalidade. Diferentemente dos outros ARFs, a CMIM apresenta um desenho institucional informal, caracterizado pela ausência de um secretariado permanente e por um formato de mecanismo de suporte à liquidez não baseado em um fundo regional de reservas, mas em um acordo multilateral de swap. Seguindo uma análise process tracing, o estudo argumenta que o desenho institucional informal da CMIM é resultado de três condições combinadas - sistêmicas, domésticas e regionais. As condições sistêmicas estão relacionadas aos desafios comuns que os estados devem superar, em qualquer processo de cooperação. Conforme proposto pela literatura de Rational Design of Institutions, a forma como os membros da CMIM superaram limitações estruturais, como incerteza, custos de soberania, custos de negociação, dificuldades no cumprimento de regras, entre outros, explica o menor grau de formalidade do arranjo regional. Em relação às condições domésticas, o trabalho demostra que o Ministério das Finanças do Japão e o Banco Central Chinês concentraram os poderes necessários (de jure e de fato) para moldar institucionalmente a CMIM, de acordo com suas preferências e interesses. Finalmente, o estudo também revela como a experiência prévia dos membros da CMIM com o regionalismo econômico associado à criação e implementação de instituições influenciou o desenho institucional informal da CMIM. Este estudo de caso reúne três importantes contribuições. Primeiro, ele contribui para o grupo de estudos sobre a CMIM, ao propor uma abordagem que busca entender o processo de institucionalização da CMIM em si mesmo. Segundo, propõe-se um modelo de análise que pode ser aplicado para examinar o desenho institucional de outros ARFs sob uma perspectiva comparada. Terceiro, oferece insights acerca de como o estudo do desenho institucional dos ARFs lança luz sobre os desenvolvimentos futuros da arquitetura financeira internacional.

Palavras-chave: Chiang Mai Initiative Mutilateralization, acordos regionais de financiamento, desenho institucional, cooperação financeira, arquitetura financeira internacional. 


\title{
Tracing the institutionalization process of informal institutions: the case study of the Chiang Mai Initiative Multilateralization
}

\begin{abstract}
The main objective of this thesis is to understand the institutional design of regional financing arrangements (RFAs). The specific goal is to understand the institutional design of the Chiang Mai Initiative Multilateralization (CMIM), which deviates from the other RFAs that currently exist in the international financial system in terms of level of formality. Differently from the other RFAs, the CMIM adopts an informal institutional design characterized by the absence of a permanent secretariat and by a format of liquidity support mechanism not based on a reserve pooling fund but on a swap multilateral agreement. Following a process tracing analysis, the study contends that the CMIM's informal institutional design is a result of three combined conditions - systemic, domestic and regional. Systemic conditions are related to the common challenges that states should overcome in any cooperation process. As proposed by the Rational Design of Institutions literature, the manner that CMIM's members have coped with structure constrains such as uncertainty, sovereignty costs, bargaining costs, enforcement problems, among others explain the low level of formality of the regional arrangement. For domestic conditions, the analysis shows that the Japanese Ministry of Finance and the Chinese Central Bank have concentrated the power needed (both de jure and de facto) for building the CMIM according to their preferences and interests. Finally, the study also demonstrates how the previous experience of CMIM's members with economic regionalism and institution-building has influenced the CMIM's informal institutional design. The CMIM case study intends to make three important contributions. First, it seeks to contribute to the literature on the CMIM by proposing an inward approach to understand the CMIM's institutionalization process per se. Second, it proposes a model of analysis that can be applied to examine the institutional design of other RFAs in a comparative perspective. Third, it offers insights on how the study of RFAs' institutional design may shed light on future developments of the international financial architecture.
\end{abstract}

Keywords: Chiang Mai Initiative Multilateralization, regional financing arrangements, institutional design, financial cooperation, international financial architecture. 


\section{Introduction}

The question of 'how and why international institutions are designed as they are' has already been asked by many international relations scholars. Some of them have conducted theoretical analyses, proposing generalizations about the conditions that explain why states choose specific institutional attributes - membership, scope of issues covered, enforcement mechanisms, delegation of authority, binding rules or non-legally binding commitments. Others have done empirical studies to test the theoretical propositions to real-world international institutions in different areas of international relations - security, trade, environment, among others (Goldstein et al., 2000; Abbot \& Snidal, 2000; Koremenos, Lipson \& Snidal, 2001; Epstein \& O’Halloran, 2008; Vaubel, 2006; Bradley \& Kelly, 2008; Vabulas \& Snidal, 2013). This thesis applies the same question to investigate the institutional design of the Chiang Mai Initiative Multilateralization (CMIM), an international institution that is part of a set of institutions known as regional financing arrangements (RFAs).

RFAs are mechanisms or agreements through which groups of countries mutually pledge financial support to countries experiencing financial difficulties in their regions. The historical analysis of the international financial system reveals that financial crises have essentially prompted the creation of RFAs, which were established to help countries facing pressures on their balance of payments related to external liquidity needs. As examples, we can mention: (i) the establishment in 1991 of the Latin America Reserve Fund to support countries in the context of the Latin American external debt crisis in the 1980s; (ii) the implementation of the CMIM by ASEAN+3 countries in the aftermath of the 1997 Asian financial crisis and; (iii) the creation of the European Stability Mechanism, the Eurasian Fund for Stabilization and Development and the BRICS Contingent Reserve Arrangement as responses to the 2008/09 global financial crisis (Mühlich, 2014). Gathering an approximate amount of US\$ 1 trillion in available financial resources (IMF, 2017), the international community has recently recognized the important role that these arrangements can play in ensuring the stability of the international financial system by functioning as complements to the IMF's funds and surveillance activities. ${ }^{1}$

Beyond the importance of RFAs in reducing countries' vulnerabilities to international capital flows and enhancing the global financial safety net, this study intends to examine the

\footnotetext{
${ }^{1}$ Joint Statement of the G20 Finance Ministers and Central Bank Governors, Paris, France, 14-15 October 2011. Available at: https://www.ief.org/_resources/files/pages/partners/g20-communique-14-15-october-2011.pdf. Accessed on 18 August 2019.
} 
outcomes of monetary and financial cooperation not in terms of the economic effectiveness of RFAs but in terms of institutional design. Generally speaking, international institutions can be classified as formal or informal organizations depending on: (i) organizing principle (if they are formed by a legal treaty or just represent shared expectations of members that do not involve binding rules); (ii) membership (if there are formal rules of membership) and; (iii) degree of organizational structure (basically, if members agree on delegating authority to an independent secretariat or permanent staff) (Pevehouse et al., 2004; Vabulas \& Snidal, 2013). Among the RFAs that currently exist in the international financial system, the CMIM can be interpreted as an 'empirically' deviant case, because it presents lower level of formality in comparison to the other arrangements. The CMIM's informal institutional design is observed primarily in two aspects: organizational structure and RFA format. Regarding the first one, the CMIM is the only RFA that does not have a permanent secretariat or staff, indicating a desire of members in a lesser extent to delegate authority and to renounce state sovereignty. With respect to the second aspect, differently from the other RFAs that are reserve pooling arrangements, the CMIM is a multilateral swap agreement. In reserve pooling arrangements, members make their financial contributions as paid-in capital transferring their funds to the regional organization; in the swap format, members' resources remain under the control and management of national monetary authorities, and funds are only transferred in case of approval of a swap activation request.

To investigate the CMIM's informal institutional design, I apply a process tracing methodology, aiming to elucidate the causal mechanisms by which certain conditions operate to produce my outcome of interest - the CMIM's informal institutional design. I examine three type of conditions: systemic, domestic and regional. Systemic conditions are analyzed through the lens of the Rational Design of Institutions (RDI) framework (Abbot \& Snidal, 2000; Koremenos, Lipson \& Snidal, 2001; Vabulas \& Snidal, 2013). According to the RDI literature, states choose institutional attributes of international institutions - membership, scope, centralization, control and flexibility - to overcome common challenges stemmed from cooperation - uncertainty, sovereignty costs, bargaining costs, enforcement problems, etc. Depending on how these institutional aspects are chosen by states, institutions can be located in different positions in a spectrum ranging from formal to informal institutions. I conduct a theory-confirming case study to verify if the hypothesized causal mechanisms proposed by the RDI literature explain the informal institutional design of the CMIM. Then, pursuing to carry out a robust application of process tracing, I consider alternative explanations for the RDI 
framework, incorporating domestic and regional conditions to the study. On domestic side, I focus the analysis on China and Japan, because they are the CMIM's main creditor countries, and I examine the role of domestic actors in shaping the CMIM's institutional design. Based on the Bureaucratic Politics Model developed by Allison (1971), I argue that the Japanese Ministry of Finance and the Chinese Central Bank have concentrated the power needed (both de jure and de facto sources of power) for building the CMIM according to their preferences and interests. Finally, by taking into account regional conditions, I follow a path dependence analysis to explore how the past experience of ASEAN+3 countries with regional economic cooperation and institution-building has also determined the CMIM's informal institutional design.

This thesis intends to contribute to the literature on the CMIM by proposing an inward approach that seeks to understand the CMIM's institutionalization process per se. Other studies have already analyzed institutional aspects of the CMIM but often oriented towards a wider context such as: the relationship of the CMIM with the IMF, the East Asian regionalism, the US influence, the Sino-Japanese power relations, among others. My objective instead is to conduct a serious examination of the CMIM's institutionalization to determine which conditions have operated through this process. More broadly, the CMIM case study sheds light to a phenomenon that has been growing in international relations and attracting attention of scholars: the proliferation of informal institutions. This work reinforces the argument that international actors have been favoring this institutional form when decide to create an international institution. Since informal institutions have been increasing in importance, the study of the CMIM helps to understand how this informal character has been spreading within the international financial architecture through new arrangements such as the bilateral swap agreements and the BRICS Contingent Arrangement.

The thesis is divided as follows. In Chapter 1, I detail the research puzzle, presenting an analysis of the historical context of the CMIM's creation and its main institutional aspects; the justifications for case selection; the research design and methodology adopted and; my contributions to the literature on the CMIM and other studies related to informal institutions, RFAs and the international financial system. Next, in chapter 3, I point out the central propositions of the RDI framework regarding formal and informal institutions and I compile the systemic conditions that are analyzed in the CMIM case study. For the analysis, I propose four conjectures or hypothesized casual mechanisms that are tested for the CMIM and make a paired comparison between the regional arrangement and the IMF, aiming to reinforce the explanation of ASEAN+3 countries' preferences for an informal institutional format for the 
CMIM. After, in chapter 3, I present the Bureaucratic Politics Model adopted to understand how domestic conditions have operated to affect the CMIM's institutional design. I identify the sources of power (de jure and de facto) that have allowed the Japanese Ministry of Finance and the Chinese Central Bank to influence the CMIM's policymaking and shape the regional arrangement in line with their interests and preferences. An extensive empirical analysis of the CMIM's institutionalization process evidences the argument proposed. To conclude this chapter, I demonstrate the CMIM's spillover effects in the international financial architecture through the analysis of two other informal arrangements that have their origins associated with the CMIM: the bilateral swap agreements signed by China and the BRICS Contingent Arrangement. Then, Chapter 4 focuses on regional conditions by making a review of East Asian economic regionalism and Asian countries' experience with liquidity support mechanisms. The chapter also reflects on the importance of considering the regional context and regional particularities in studies of monetary and financial cooperation and institution-building. Finally, the conclusion section summarizes the results achieved and presents the theoretical implications of the study and future research developments raised by it. 


\section{Conclusion}

Among the RFAs that are currently present in the international financial system, the CMIM appears as an 'empirically' deviant case due to its lower level of formality in comparison to the others. The regional Asian arrangement is not a regional fund per se but a multilateral swap agreement whereby the ASEAN+3 countries have agreed on not delegating authority to a regional organization (or permanent secretariat) to manage funds and conduct institution's operational activities. Through the adoption of a swap institutional format, members have ensured the flexibility and control over the management of their financial contributions, i.e. their foreign exchange reserves. The objective of the thesis was to investigate how and why the CMIM has maintained this informal institutional design since its origins. Following a process tracing methodology, the study sought to uncover the causal mechanisms that have led members to opt for establishing an informal institution. In such sense, the main contribution of this research was to examine the institutionalization process of the CMIM per se. In contrast to previous studies on the CMIM, this thesis was not intended to assess the CMIM's institutional framework in terms of its effectiveness in order to make predictions if the regional arrangement can become independent from the IMF; neither evaluate the CMIM's institution-building with respect to other initiatives in the wider context of East Asian economic regionalism; nor analyze the impacts of power relations between China and Japan and the influence of the US on the CMIM's developments. The thesis has focused on identifying which conditions and how they have operated to determine the existing institutional attributes of the arrangement.

The chain of evidences and steps constructed to make inferences about how the CMIM's institutionalization process took place and how it generated the outcome of interest - the informal institutional design - was characterized by a combination of systemic, domestic and regional conditions. To summarize, the causal process mechanism proposed here works as follows. The previous experience of ASEAN+3 countries with economic cooperation and institution-building has fomented the original preferences of states for more informal arrangements based on flexibility, non-binding commitments, imprecise rules, non-interference in domestic issues and consensus-diplomacy - the so-called 'ASEAN way'. These preferences have affected states' choices regarding the CMIM's institutional attributes in terms of flexibility autonomy, control, bureaucracy and softer rules. As shown in chapter 2, due to the traumatic experience of Asian countries with the IMF emergency loans in the aftermath of the 1997 Asian 
financial crisis, states have agreed on establishing a more informal liquidity support arrangement that involved lower costs - transaction, sovereignty, operating, change and exit costs - and offered superior institutional solutions and governance benefits such as less constraints, more flexibility to deal with uncertainty and reduced impact on state's authority and sovereignty. To recapture some of the informal institutional attributes discussed above, states have decided on: the swap format to maintain control over the management of their foreign exchange reserves, which comprise members' financial contributions to the CMIM; the establishment of lenient enforcement mechanisms and vague escape clauses for members not willing to provide funds in case of swap activation; the adoption of less rigid ex ante conditionalities and non-clearly defined ex post conditionalities (for the IMF-delinked portion); not delegating authority and independence to AMRO performs its activities neither transforming it as CMIM's official permanent secretariat. This part of the process tracing has corroborated the established propositions of the RDI framework regarding states' choices between formal and informal institutions. The process tracing, however, has not just focused on a top-down approach in which the unitary state assumption applied by RDI scholars emphasizes the central role of states as the entities engaging in activities that transmit causal forces through causal mechanisms. In chapter 3, I adopted a bottom-up analysis that has looked beyond the state level, putting domestic actors as the center agents of the CMIM's institutionalization process. Here, the process tracing has shown that choices regarding the institutional design of international institutions are made by domestic agents acting on behalf of the state. Most importantly, these institutional choices are not just a result of systemic conditions as proposed by the RDI literature, i.e. how players overcome common challenges inherent to any cooperation process - uncertainty, sovereignty costs, bargaining costs, enforcement problems, among others. To better understand the institutional design of international institutions, it is essential to consider the interplay between domestic and systemic conditions. In such sense, the operationalization of the causal mechanism has shown how domestic politics have affected the CMIM's informal institutional design through a chain of observable manifestations that have pointed out: first, the sources of power (de jure and de facto) that have allowed the Japanese Ministry of Finance and the Chinese Central Bank being the central government agencies to influence the CMIM's policymaking; second, their preferences with respect to institutional format and; third, the systemic conditions stemmed from international politics that might have constrained domestic agents' decisions and actions. The empirical analysis of the CMIM's institutionalization process has confirmed the central 
role played by the Japanese Ministry of Finance and the Chinese Central Bank in shaping the CMIM's informal institutional design.

The model of analysis proposed by this study to investigate the institutionalization process of the CMIM and its institutional design can also be applied to the other RFAs in a comparative perspective. To date, there is not any comparative study of the RFAs focusing on institutionalization process. A comparative analysis would help to understand the role of ministries of finance and central banks in different regional contexts as well as would contribute to comprehend how previous experiences with multilateral initiatives and systemic conditions related to cooperation processes have affected states' choices in other regions regarding the institutional design of RFAs. A comparative analysis would enable to determine the key variables or conditions among those suggested here (systemic, domestic and regional) that operate in RFAs' institutionalization process, making possible to claim for stronger theoretical generalizations and reinforce or disconfirm established propositions such as those offered by the RDI literature.

The study of RFAs, in particular the issue of institutional design, has been assuming substantial importance in understanding the prevailing configuration of the international financial system and in making predictions about its future architecture. The rise of RFAs has been characterized essentially by the dissatisfaction of emerging powers and developing countries with the reform process in global financial governance and the reluctance in relying on the IMF to tackle balance of payments difficulties. The amount of financial resources available through regional solutions indicates that global multilateral institutions may play a more limited role in ensuring international financial stability (Chin, 2010). Understanding the institutional design of the RFAs sheds light on how the international financial architecture may evolve. By analyzing the institutionalization process and institutional attributes of RFAs, we can observe if the international financial order is heading towards a more fragmented and diffused framework in which regional institutions can operate independently from global institutions; or towards a more cooperative framework in which regional institutions develop institutional mechanisms to coordinate activities with institutions at different levels - global, regional, bilateral and multilateral. In case of the CMIM, the analysis has shown that the regional arrangement may contribute to foment a more cooperative and informal financial order in the sense that the BRICS CRA replicates the CMIM's swap format and formal link with the IMF, and the bilateral swap agreements signed by China maintain the non-binding commitment 
of providing funds to regional neighbors and may act as complements to the CMIM's and the IMF's liquidity assistance with quicker disbursement of funds. 


\section{References}

Abbott, K., \& Snidal, D. (2000). Hard and Soft Law in International Governance. International Organization 54, 3, Summer, pp. 421-456.

Acharya, A. (1997). Ideas, identity, and institution building: From the "ASEAN way" to the “Asia- Pacific way". The Pacific Review, 10(3), 319-346.

Acharya, A. (2014). International Relations Theory and the "Rise of Asia". In Saadia M. Pekkanen, John Ravenhill and Rosemary Foot (eds), Oxford Handbook of The International Relations of Asia. Oxford University Press, p. 120-137.

ADB. (2008). Emerging Asian Regionalism: A Partnership for Shared Prosperity. Manila: ADB.

Asian Development Bank (ADB). (2011). Supporting and Enhancing Regional Surveillance for ASEAN+3 and the Chiang Mai Initiative Multilateralization. Project Number: 42065 Regional-Capacity Development Technical Assistance (R-CDTA).

Allison, G.T. (1971). Essence of Decision: Explaining the Cuban Missile Crisis. Boston: Little, Brown.

Allison, G. \& Zelikow, P. (1999). Essence of Decision: Explaining the Cuban Missile Crisis. $2^{\text {nd }}$ edn New York: Longman.

Amyx, J. (2000). The Ministry of Finance (MOF) at the Crossroads. Pacific Economic Papers, No. 301.

Amyx, J. (2002). Moving beyond bilateralism? Japan and the Asian Monetary Fund. Pacific Economic Papers, No. 331.

Amyx, J. (2004). Japan and the Evolution of Regional Financial Arrangements in East Asia. In Beyond Bilateralism: US-Japan Relations in the New Asia-Pacific, edited by Ellis Krauss and T. J. Pempel, 198-218. Stanford, CA: Stanford University Press.

Amyx, J. (2005). What Motivates Regional Financial Cooperation in East Asia Today? Asia Pacific Issues, 76. 1-8.

Amyx, J. (2008). Regional Financial Cooperation in East Asia since the Asian Financial Crisis. In MacIntyre, Andrew, T.J. Pempel, and John Ravenhill (eds.) Crisis as Catalyst: Asia's Dynamic Political Economy. Ithaca: Cornell University Press: 117-139.

Armijo, L. \& Katada, S. (2014). The Financial Statecraft of Emerging Powers - Shield and Sword in Asia and Latin America. Palgrave Macmillan.

Asami, T. (2005). Chiang Mai Initiative as the Foundation of Financial Stability in East Asia. ASEAN+3 Research Group Studies. Online. Available at: www.aseansec.org/17905.pdf. 
Azis, I. (2013). Inadequate Regional Financial Safety Nets Reflect Complacency. ADBI Working Paper Series, No. 411.

Baek, S. G., \& Chi-Young Song (2002). Is Currency Union a Feasible Option in East Asia? In H. Choo and Y. Wang (eds), Currency Union in East Asia. Korea Institute for International Economic Policy.

Barnes, J. \& Weller, N. (2011). The Promise of Process Tracing: Case selection in a World of Causal Complexity. Available at SSRN: https://ssrn.com/abstract=1804128 or http://dx.doi.org/10.2139/ssrn.1804128

Bell, S. \& Feng, H. (2013). The Rise of the People's Bank of China - The Politics of Institutional Change. Harvard University Press.

Bell, S. \& Feng, H. (2014). How Proximate and 'Meta-Institutional' Contexts Shape Institutional Change: Explaining the Rise of the People's Bank of China. Political Studies, Volume: 62 issue: 1, page(s): 197-215.

Bayoumi, T., \& Eichengreen, B. (1994). One money or many? Analyzing the prospects for monetary unification in various parts of the world. Princeton Studies in International Finance, 76.

Bayoumi, T., \& Paolo, M. (1999). The Suitability of ASEAN for a Regional Currency Arrangement. IMF Working Paper WP/99/162.

Beach, D., \& Pedersen, R. B. (2013). Process-Tracing Methods Foundations and Guidelines. University of Michigan Press.

Bénassy-Quéré, A., \& Coeuré, B. (2005). Big and small currencies: The regional connection. In P. Artus, A. Cartapanis, \& F. Legros (eds.), Regional currency areas in financial globalization: A survey of current issues. Cheltenham: Edward Elgar, p. 182-199.

Bennett, A., \& Checkel, J. T. (2014). Process Tracing, From Metaphor to Analytic Tool. Cambridge University Press.

Bhagwati, J. (1998). The Capital Myth: The Difference between Trade in Widgets and Dollars. Foreign Affairs, 77.

Bisley, N. (2007). East Asia's Changing Regional Architecture: Towards an East Asian Economic Community? Pacific Affairs, Vol. 80, No. 4, Special Forum: East Timor's Truth Commission (Winter, 2007/2008), pp. 603-625.

Börzel, T. A. (2011). Comparative regionalism. A new research agenda. KFG The Transformative Power of Europe Working Paper No. 28. Berlin: Freie Universität.

Börzel, T. A., \& Risse, T. (2012). When Europeanisation meets diffusion: Exploring new territory. West European Politics, 35, 192-207.

Bradley, C., \& Kelly, J. (2008). The Concept of International Delegation. Law and Contemporary Problems 71, 1: 1-36. 
Breslin, S. (2003). Paradigm shifts and time-lags? The politics of financial reform in the People's Republic of China. Asian Business and Management 2: 143-66.

Breslin, S. (2009). Understanding China's Regional Rise: Interpretations, Identities and Implications. International Affairs, 85(4): 817-835.

Cai, K. (2010). The Politics of Economic Regionalism. Explaining Regional Economic Integration in East Asia. New York: Palgrave MacMillan.

Capannelli, G., \& Kawai, M. (2014). The Political Economy of Asian Regionalism: Issues and Challenges. In Giovanni Capannelli and Masahiro Kawai (eds), The Political Economy of Asian Regionalism. Springer and Asian Development Bank Institute, p. 1-18.

Capannelli, G., \& Tan, S. (2014). Institutions for Asian Integration: Innovation and Reform. In Giovanni Capannelli and Masahiro Kawai (eds), The Political Economy of Asian Regionalism. Springer and Asian Development Bank Institute, p. 143-167.

Cargill, T.F., Hutchison, M.M. and Itô, T. (1997). The Political Economy of Japanese Monetary Policy. Cambridge, MA: The MIT Press.

Cargill, T.F., Hutchison, M.M. and Itô, T. (2000). Financial Policy and Central Banking in Japan. Massachusetts: Massachusetts Institute of Technology.

Central Banking. (2018). Who is Yi Gang? At https://www.centralbanking.com/centralbanks/governance/people/3424591/who-is-yi-gang.

Chey, H. (2009). The Changing Political Dynamics of East Asian Financial Cooperation: The Chiang Mai Initiative. Asian Survey, Vol. 49 No. 3, May/June 2009; (pp. 450-467).

Chin, G. (2010). Remaking the architecture: the emerging powers, self-insuring and regional insulation. International Affairs 86:3 pp. 693-715.

Ciorciari, J. (2011). Chiang Mai Initiative Multilateralization International Politics and Institution-Building in Asia. Asian Survey, Vol. 51, No. 5 (September/October 2011), pp. 926952.

Clift, B. (2014). Comparative Political Economy - States, Markets and Global Capitalism. New York: Palgrave MacMillan.

Cohen, B. (2004). The future of money. Princeton, NJ: Princeton University Press.

Cohen, B. (2013). Currency and State Power. In M. Finnemore and J. Goldstein (eds) Back to Basics: State Power in a Contemporary World, pp. 159-77. Oxford: Oxford University Press.

Cohen, B. \& Benney, T. (2013). What does the international currency system really look like? Review of International Political Economy, 21(5): 1017-41.

Cohen, B. (2017). Renminbi Internationalization: A Conflict of Statecrafts. Research Paper, The Royal Institute of International Affairs Chatham House. 
Cukierman, A. (1992). Central Bank Strategy, Credibility, and Independence: Theory and Evidence. MIT Press.

Curtis, G.L. (ed.) (2002): Policymaking in Japan. Defining the Role of Politicians. Tokyo: Japan Center for International Exchange.

Dai, X. (1998). 50 Years of the People's Bank of China: The Evolution of a Central Banking System 1948-1998. Beijing: Zhongguo jinrong chubanshe.

DeGrauwe, P., \& Mongelli, F. P. (2005). Endogeneities of optimum currency areas: What brings countries sharing a regional currency together? Working Paper No. 468. Frankfurt: ECB.

Destais, Ch. (2014). Central Bank Currency Swaps and the International Monetary System. Policy Brief 2014-05. Paris. Centre d'Etudes Prospectives et d'Informations Internationales.

Dieter, H. (2000). Monetary regionalism: Regional integration without financial crises. Working Paper No. 52/00. Coventry: University of Warwick.

Dieter, H. \& Higgott, R. (2003). Exploring alternative theories of economic regionalism: from trade to finance in Asian co-operation? Review of International Political Economy, 10:3, 430454.

Dieter, H. (2006). The Advancement of Monetary Regionalism in East Asia. In Fritz, Barbara and Metzger, Martina (eds), New Issues in Regional Monetary Coordination - Understanding North-South and South-South Arrangements. London: Palgrave, 188-214.

Dieter, H. (2008). Monetary and Financial Cooperation in Asia. Motives, Sequencing and Political Obstacles. GARNET Working Paper No. 16/07, Coventry, UK: University of Warwick.

Downs, A. (1967). Inside bureaucracy. Boston: Little Brown.

Duran, C. (2017). O Prestamista Internacional de Última Instância para Países Emergentes: Um Contrato de Swap Cambial? Revista Tempo do Mundo, v. 3, n. 1.

Dwyer, J.H. (2004). Explaining Central Bank Reform in Japan. Social Science Japan Journal, 7(2), 245-262.

Dwyer, J. H. (2012). Explaining the Politicization of Monetary Policy in Japan. Social Science Japan Journal, 15(2), 179-200.

Edwards, R. (1985). International monetary collaboration. Transnational Publishers: New York.

Eichengreen, B., \& Bayoumi, T. (1998). Is Asia an optimum currency area? Can it become one? Regional, global and historical perspectives on Asian monetary relations. In Collignon, Stefan, J. Pisani-Ferry \&Yung Chul. Park (eds), Exchange Rate Policies in Emerging Asian Countries. London: Routledge. 
Epstein, D., \& O'Halloran, S. (2008). Sovereignty and Delegation in International Organizations. Law and Contemporary Problems 71, 1: 77-92.

Evans, P. (2005). Between Regionalism and Regionalization: Policy Networks and the Nascent East Asian Institutional Identity. In Pempel, T. J. (ed.), Remapping East Asia: The Construction of a Region. Ithaca, NY: Cornell University Press, 195-215.

Fearon, J. D. (1998). Bargaining, Enforcement, and International Cooperation. International Organization 52(2): 269-305.

Feldstein, M. (1998). Refocusing the IMF. Foreign Affairs 77(2).

Feng, H. (2006). How the People's Bank is Shaping China's Financial Sector. Central Banking 17(1): 35-41.

Feng, H. (2007). China’s New Reserve Strategy. Central Banking 17(3): 29-36.

Feng, H. (2011). The Three Trillion Dollar Question. Central Banking 21(4): 26-30.

Feng, H. (2013). China's New Financial and Regulatory Architects. Central Banking. Available at: https://www.centralbanking.com/central-banking-journal/feature/2266644/china-s-newfinancial-and-regulatory-architects.

Frankel, J. A., \& Rose, A. K. (1997). Is EMU more justifiable ex post than ex ante? European Economic Review, 41(3-5), 753-760.

Frankel, J. A. (2011). Historical Precedents for Internationalization of the RMB, CGS/IIGG Working Paper, New York: Council on Foreign Relations, http://www.cfr.org/china/historicalprecedents-internationalization-rmb/p26293.

Fritz, B., \& Metzger, M. (Eds.). (2006). New issues in regional monetary coordination. New York, NY: Palgrave Macmillan.

Fritz, B., \& Mühlich, L. (2010). South-south monetary integration: The case for a research framework beyond the theory of optimum currency area. International Journal of Public Policy, 6(1-2), 118-135.

Fritz, B. \& Mühlich, L. (2014). Regional Monetary Co-operation in the Developing World Taking Stock. Working Paper for the UNCTAD project "Strengthening pro-growth macroeconomic management capacities for enhanced regional financial and monetary cooperation among selected countries of Latin America and the Caribbean, and West and Central Africa."

Fritz, B. \& Mühlich, L. (2015). Varieties of regional monetary cooperation: a tool for reducing volatility in developing economies? Contemporary Politics, 21:2, 127-144.

Fritz, B. \& Mühlich, L. (2018). Safety for Whom? The Scattered Global Financial Safety Net and the Role of Regional Financial Arrangements. Open Economies Review, volume 29, pages 981-1001. 
Frost, E. (2008). Asia's New Regionalism. Boulder: Lynne Reinner.

Gerring, J. (2004). What Is a Case Study and What Is It Good for? American Political Science Review, Volume 98, Issue 2, pp. 341-354.

George, A. L., \& Bennett, A. (2005). Case Studies and Theory Development in the Social Sciences. MIT Press Cambridge, Massachusetts London, England.

Gilpin, R. (1981). War and Change in World Politics. Cambridge: Cambridge University Press.

Goh, E. (2013). The Struggle for Order: Hegemony, Hierarchy, and Transition in Post-Cold War East Asia, Oxford: Oxford University Press.

Goldberg, L.S.; \& Tille, C. (2008). Vehicle Currency Use in International Trade. Journal of International Economics 76(2): 177-92.

Goldstein, J., Kahler, M., Keohane, R., \& Slaughter, A. (eds). (2000). Legalization and World Politics. Cambridge: Cambridge University Press.

Goto J., \& Hamada, K. (1994). Economic preconditions for Asian regional integration. In: Ito, T. \& A. O. Krueger (eds), Macroeconomic Linkages. Chicago: University of Chicago Press.

Gourevitch, P. (1986). Politics in Hard Times: Comparative Responses to International Economic Crises. Cornell University Press.

Gourevitch, P. (2008). Containing the Oligarchs: The Politics of Corporate Governance Systems in East Asia. In MacIntyre, Andrew, T.J. Pempel, and John Ravenhill (eds.), Crisis as Catalyst: Asia's Dynamic Political Economy. Ithaca: Cornell University Press: 70-92.

Grabel, I. (2019). Continuity, Discontinuity and Incoherence in the Bretton Woods Order: A Hirschmanian Reading. Development and Change 50(1): 46-71.

Green, M., \& B. Gill. (2009). Asia's New Regionalism: Cooperation, Competition, and the Search for Community. New York: Columbia University Press.

Grimes, W. (2001). Unmaking the Japanese Miracle. Ithaca, New York: Cornell University Press.

Grimes, W. (2006). East Asian financial regionalism in support of the global financial architecture? The political economy of regional nesting. Journal of East Asian Studies, 6(3): 353-380.

Grimes, W. (2011). The Asian Monetary Fund Reborn? Implications of Chiang Mai Initiative Multilateralization. Asia Policy, Number 11, 79-104.

Grimes, W. (2014). The Rise of Financial Cooperation Since the Asian Financial Crisis. In Saadia Pekkanen, John Ravenhill, and Rosemary Foot, eds., Oxford Handbook of the International Relations of Asia (Oxford, 2014), pp. 285-305.

Grimes, W. (2015). East Asian financial regionalism: why economic enhancements undermine political sustainability. Contemporary Politics, Vol. 21, No, 2, 145-160. 
Guo, Y. (2002). Banking Reforms and Monetary Policy in the People's Republic of China: Is the Chinese Central Banking System Ready for Joining the WTO? Basingstoke, UK: Palgrave Macmillan.

Halpern, N. (1992). Information Flows and Policy Coordination in the Chinese Bureaucracy. In Kenneth G. Lieberthal and David M. Lampton (eds), Bureaucracy, Politics and Decision Making in Post-Mao China, University of California Press, Ltd.

Haggard, S. (1997). Regionalism in Asia and the Americas. In The Political Economy of Regionalism, edited by Edward Mansfield and Helen Milner, 20-49. New York: Columbia University Press.

Haggard, S. (2013). The Organizational Architecture of the Asia-Pacific: Insights from the New Institutionalism. In Miles Kahler and Andrew MacIntyre (eds), Integrating Regions: Asia in Comparative Context. Stanford, CA: Stanford University Press, 195-221.

Haggard, S. (2014). The Liberal View of the International Relations of Asia. In Saadia M. Pekkanen John Ravenhill and Rosemary Foot (eds), Oxford Handbook of the International Relations of Asia. Oxford University Press, p. 45-63.

Hamanaka, S. (2009). Asian Regionalism and Japan: The Politics of Membership. In Regional Diplomatic, Financial and Trade Groups. New York: Routledge.

Hamada, K., Reszat, B., \& Volz, U. (2009). Towards Monetary and Financial Integration in East Asia. UK: Edward Elgar Publishing Limited.

Hamilton-Hart, N. (2006). Banking systems a Decade after the Crisis. In MacIntyre, Andrew, T.J. Pempel, and John Ravenhill (eds.), Crisis as Catalyst: Asia's Dynamic Political Economy. Ithaca: Cornell University Press, 45-69.

Hamrin, C. L.; \& Zhao, S. (1995). Introduction: Core Issues in Understanding the Decision Process. In Carol Lee Hamrin and Suisheng Zhao (eds), Decision-Making in Deng's China: Perspective from Insiders. Armonk, NY; M.E.Sharpe.

Harris, S. (2000). Asian multilateral institutions and their response to the Asian economic crisis: The regional and global implications. The Pacific Review 13(3): 495-516.

Hawkins, A.; Rahman, J.; Williamson, T. (2014). Is the global financial safety net at a tipping point to fragmentation? Econ Roundup 1:1-20.

Hay, C. (2002). Political Analysis: A Critical Introduction. Basingstoke: Palgrave Macmillan.

Hayashi, S. (2006). Japan and East Asian Monetary Regionalism: Toward a Proactive Leadership Role? London: Routledge.

Henning, R. (1994). Currencies and Politics in the United States, Germany, and Japan. Washington: Institute for International Economics. 
Henning, R. (2002). East Asian Financial Cooperation. Policy Analyses in International Economics 68. Washington, D.C.: Peterson Institute for International Economics.

Henning, R. (2005). Systemic Contextualism and Financial Regionalism: The Case of East Asia URL: http://www.cgu.edu/include/1118_henning1.doc.

Henning, R. (2009). The Future of the Chiang Mai Initiative: An Asian Monetary Fund? Peterson Institute for International Economics, Number Pb09-5.

Henning, R. (2011). Coordinating regional and multilateral financial institutions. Working Paper No. 11-9. Washington, DC: Peterson Institute of International Economics.

Henning, R. (2016). The Global Liquidity Safety Net: Precautionary Facilities and Central Bank Swaps, in C.R. Henning and A.Walter (eds) Global Financial Governance Confronts the Rising Powers: Emerging Perspectives on the New G20, pp. 119-50. Waterloo, Canada: Centre for International Governance Innovation.

Henning, R. (2017). Tangled Governance: International Regime Complexity, the Troika, and the Euro Crisis. New York: Oxford University Press.

Higgott, R. (1998). The Asian Economic Crisis: A Study in the Politics of Resentment. New Political Economy. 3(3): 333-356.

Hill, H., \& Menon, J. (2012). Financial Safety Nets in Asia: Genesis, Evolution, Adequacy, and Way Forward. ADBI Working Paper Series.

Hill, C. (2003). The Changing Politics of Foreign Policy. Basingstoke: Palgrave Macmillan.

Hirschman, A.O. (1967). Development Projects Observed. Washington, DC: Brookings Institution.

Hiwatari, N. (2000). The Reorganization of Japan's Financial Bureaucracy: The Politics of Bureaucratic Structure and Blame Avoidance', in: Hoshi, T. and Patrick, H. (eds.): Crisis and Change in the Japanese Financial System. Boston/Dodrecht/London: Kluwer Academic Publishers, 109-136.

Hollis, M.; \& Smith, S. (1991). Explaining and Understanding International Relations. Oxford: Clarendon Press.

Hori, H. (2005). The Changing Japanese Political System - The Liberal Democratic Party and the Ministry of Finance. London and New York: Routledge.

Hudson, V. M. (2002). Foreign Policy Decision-Making: A Touchstone for International Relations Theory in the Twenty-first Century. In Foreign Policy Decision-Making (Revisited), edited by R. C. Snyder, H. W. Bruck and B. Sapin, pp. 1-20. New York: Palgrave-Macmillan.

Hudson, V. M. (2003). Foreign Policy Analysis: Classic and Contemporary Theory. New York: Rowman \& Littlefield. 
Huotari, M. (2016). Finding a new role in the East Asian financial order - China's hesitant turn towards leadership. In Sebastian Harnisch, Sebastian Bersick and Jörn-Carsten Gottwald (eds) China's International Roles Challenging or supporting international order? NY: Routledge.

Hurrel, A. (2007). One World? Many Worlds? The Place of Regions in the Study of International Society. International Affairs, 83 (1): 127-146.

IIMA, (2005). Research Papers and Policy Recommendations on Economic Surveillance and Policy Dialogue in East Asia. ASEAN+3 Research Studies. Available at: https://asean.org/?static post=external-relations-asean-3-asean3-research-group-studies.

Iwata, K. (2009). Can we trust the Bank of Japan? Tokyo Kodansha.

Jiang, Y. (2010). Response and Responsibility: China in East Asian Financial Cooperation. The Pacific Review, 23(5): 603-623.

Jiang, Y. (2013). China's Policymaking for Regional Economic Cooperation. Palgrave MacMillan, UK.

Jupille, J.; Mattli, W.; Snidal, D. (2013). Institutional Choice and Global Commerce. (Cambridge).

Kahler, M. (2000). Legalization as Strategy: The Asia-Pacific Case., International Organization, 54(3): 549-71.

Kahler, M. (2016). Regional Challenges to Global Governance. In Miles Kahler, C. Randall Henning, Chad P. Bown, Hongying Wang, Erik Voeten, Paul D. Williams (eds), Global Order and the New Regionalism - Discussion Paper Series on Global and Regional Governance, NY: Council on Foreign Relations.

Kaminsky, G., \& Reinhart, C. (1999). The Twin Crises: The Causes of Banking and Balance of Payments Problems. American Economic Review. Vol. 89, No. 3, p.473-500.

Kanegae, T. (1996). On the Reform of the Central Banking System in Japan. In: Matsugi, T., Oberhauser, A. and Schober, F. (eds.): Integration and Adjustment of Global Economies. Berlin: Duncker \& Humblot, 129-158.

Katada, S. (2014). Why Was the CMI Possible? Embedded Domestic Preferences and Internationally Nested Constraints in Regional Institution Building in East Asia. Paper presented at FLACSO-ISA Conference.

Katada S.N.; Sohn I. (2014). Regionalism as Financial Statecraft: China and Japan's Pursuit of Counterweight Strategies. In: Armijo L.E., Katada S.N. (eds) The Financial Statecraft of Emerging Powers. International Political Economy Series. Palgrave Macmillan, London.

Katada, S. (2017). In pursuit of stability: evolution of Asia's regional financial architecture. The Pacific Review, 30:6, 910-922. 
Katô, J. (2002). Politicians, Bureaucrats and Interest Groups in Japan. In: Loewenberg, G., Squire, P. and Kiewiet, D.R. (eds.): Legislatures: comparative perspectives on representative Assemblies. University of Michigan Press, 314-328.

Katzenstein, P. (1997). Network Power - Japan and Asia. Edited by Peter J. Katzenstein and Takashi Shiraishi. Cornell University Press.

Katzenstein, P. (2005). A World of Regions. Ithaca, NY: Cornell University Press.

Kawai, M. (2007). Evolving Economic Architecture in East Asia. ADB Institute Discussion Paper No. 84.

Kawai, M., \& Houser, C. (2007). Evolving ASEAN+3 ERPD: Towards Peer Reviews or Due Diligence? Asian Development Bank Institute Discussion Paper 79. Tokyo: Asian Development Bank Institute.

Kawai, M. (2010). Reform of the International Financial Architecture: An Asian Perspective. The Singapore Economic Review, Vol. 55, No. 01, pp.207-242.

Kawai, M. (2015). From the Chiang Mai Initiative to an Asian Monetary Fund. Paper presented at the "Future Global Reserve System" conference, Tokyo, March 17-18.

Kawakita, T. (1995). The Bank of Japan. Tokyo: Iwanami Shoten.

Kenen, P. B. (1969). The theory of optimum currency areas: An eclectic view. In R. Mundell \& A. Swoboda (Eds.), Monetary problems of the international economy. Chicago, IL: University of Chicago Press, p. 41-59.

Keohane, R., \& Nye, J. (1977). Power and Interdependence: World Politics in Transition. Boston, MA: Little, Brown.

Keohane, R. (1984). After hegemony: cooperation and discord in the world political economy. Princeton: Princeton University Press.

Keohane, R. (1989). International Institutions and State Power: Essays in International Relations. Theory. Boulder, Colo.: Westview.

Kilby, C. (2006). Donor Influence in Multilateral Development Banks: The Case of the Asian Development Bank. Review of International Organizations, 1 (2): 173-195.

Kindelberg, C. P. (1981). Dominance and leadership in the international economy: Exploitation, public goods and free rides. International Studies Quarterly, 25(2), 242-254.

Koremenos, B., Lipson, C., \& Snidal, D. (2001). The Rational Design of International Institutions. International Organization 55, 4, Autumn, pp. 761-799.

Krampf, A., \& Fritz, B. (2015). Coping with financial crises: explaining variety in regional arrangements, Contemporary Politics, 21:2, 117-126. 
Krapohl, S. (2015). Financial crisis as catalysts for regional cooperation? Chances and obstacles for financial integration in ASEAN+3, MERCOSUR and the Eurozone. Contemporary Politics, $21: 2,161-178$.

Krasner, S.D. (1982). Structural causes and regimes consequences: regimes as intervening variable. In International Regimes. Ithaca: Cornell University Press.

Kring, W.; \& Gallagher, K. (2019). Strengthening the Foundations? Alternative Institutions for Finance and Development. Development and Change 50(1): 3-23.

Kring, W. \& Grimes, W. (2019). Leaving the Nest: The Rise of Regional Financial Arrangements and the Future of Global Governance, Development and Change 50(1): 72-95.

Laurens, B.; Arnone, M.; Segalotto, J.F.; Sommer, M. (2009). Central Bank Autonomy: Lessons from Global Trends. IMF Staff Papers, volume 56, pages 263-296.

Lee, Y. W. (2006). Japan and the Asian Monetary Fund: An Identity-Intention Approach. International Studies Quarterly 50(2): 339-66.

Lee, J. H., \& Barro, R. (2006). Currency Union in East Asia. http://www.aric.adb.org/pdf/ LeeCurrencyUnion1031.pdf.

Lee, Y.W. (2008). The Japanese Challenge to the American Neoliberal World Order. Redwood City, CA, Stanford University Press.

Lee, Y. W. (2009). Regional Financial Solidarity without the United States: Contested Neoliberalism in East Asia. East Asian Institute Security Initiative Working Paper, no. 1.

Liao, S. \& McDowell, D. (2015). Redback Rising: China's Bilateral Swap Agreements and Renminbi Internationalization. International Studies Quarterly, 59:3 (September), pp. 401-22.

Lieberthal, K.; \& Lampton, D. (1992). Bureaucracy, Politics and Decision Making in PostMao China, University of California Press, Ltd.

Lieberthal, K.; \& Oksenberg, M. (1988). Policymaking in China: Leaders, Structures, and Processes. Princeton, NJ: Princeton University Press.

Liew, L. (1995). Gradualism in China's Economic Reform and the Role of the Strong Central State. Journal of Economic Issues 29(3): 883-95.

Lijphart, A. (1971). Comparative Politics and the Comparative Method. The American Political Science Review, Vol. 65, No. 3. Sep, pp. 682-693.

Mabuchi, M. (1997). Why was the MOF hounded? Tokyo: Chuo Koronsha.

Mahbubani, K. (1995). The Pacific Way. Foreign Affairs 74(1): 100-111.

Mansfield, E. D., \& Milner, H. V. (1999). The new wave of regionalism. International Organization, 53, 589-627. 
Mansfield, E. D., \& Pevehouse, J. C. (2003). Institutions, Interdependence, and International Conflict. In Gerald Schneider, Katherine Barbieri and Nils Petter Gleditsch (eds), Globalization and Armed Conflict. Lanham, MD: Rowman \& Littlefield, p. 233-50.

McDowell, D., \& Steinberg, D. (2017). Systemic Strengths, Domestic Deficiencies: The Renminbi's Future as a Reserve Currency. Journal of Contemporary China, Volume 26, 2017 - Issue 108.

McDowell, D. (2019). The (Ineffective) Financial Statecraft of China's Bilateral Swap Agreements. Development and Change 50(1): 122-143.

McKay, J.; Volz, U.; Wölfinger, R. (2011). Regional Financing Arrangements and the Stability of the International Monetary System. Journal of Globalization and Development 2/1 Article 5 .

McKinnon, R. (1963). Optimum currency areas. American Economic Review, 53, 717-725.

Mikitani, R.; \& Kuwayama, P.H. (1998). Japan's New Central Banking Law: A Critical View, Center on Japanese Economy and Business, Working Paper, Columbia University.

Miller, G.P. (1996). Decision-Making at the Bank of Japan. Law and Policy in International Business, 28(1), 1-47.

Miyazawa, K. (1998). Towards a New International Financial Architecture. Speech by Mr. Kiichi Miyazawa, the Minister of Finance, at the Foreign Correspondents Club of Japan. December 15, 1998.

Moessner, R., \& Allen, W. (2010). Options for Meeting the Demand for International Liquidity During Financial Crises. BIS Quarterly Review, 51-61.

Mohanty, M. S., \& Turner, P. (2006). Foreign Exchange Reserve Accumulation in Emerging Markets: What are the Domestic Implications? BIS Quarterly Bulletin. September. 39-52.

Moravcsik, A. (1997). Taking Preferences Seriously: A Liberal Theory of International Politics. International Organization 51, 4, Autumn, pp. 513-53.

Motoyoshi, M. (2006). The Bank of Japan - Insider. Tokyo: Kôsaidô Shuppan Sha.

Mühlich, L. (2014). Advancing Regional Monetary Cooperation. The Case of Fragile Financial Markets. New York: Palgrave Macmillan.

Munakata, N. (2006). Has Politics Caught Up with the Markets? In Search of East Asian Economic Regionalism. In Peter J. Katzenstein. and Takashi Shiraishi (eds.), Beyond Japan: The Dynamics of East Asian Regionalism. Ithaca: Cornell University Press, 130- 157.

Mundell, R. (1961). A theory of optimum currency areas. American Economic Review, 51, 657665.

Muramatsu, M.; \& Scheiner, E. (2007). The Slow Government Response to Japan's Bank Crisis: A Principal-Agent Analysis. Transcript. 
Murase, T. (2004). A Zone of Asian Monetary Stability. Canberra: Asia Pacific Press.

Nakasô, H. (2001). The Financial Crisis in Japan during the 1990s: How the Bank of Japan responded and Lessons learned. Bank for International Settlements. BIS Papers, No. 6.

Narine, S. (2003). The Idea of An "Asian Monetary Fund": The Problems Of Financial Institutionalism In The Asia-Pacific. Asian Perspective, Vol. 27, No. 2 (2003), pp. 65-103.

Naughton, B. (1996). Growing Out of the Plan: Chinese Economic Reform, 1978-1993. Cambridge University Press.

Naughton, B. (2004). An Economic Bubble? Chinese Policy Adapts to Rapidly Changing Conditions. China Leadership Monitor, 9 (Winter).

Naughton, B. (2008). A Political Economy of China's Economic Transition, in L. Brant and T. Rawski (eds), China's Great Economic Transformation. Cambridge: Cambridge University Press, pp. 91-135.

Neack, L. (2003). The New Foreign Policy: U.S. and Comparative Foreign Policy in the $21^{\text {st }}$ Century. Lanham: Rowman \& Littlefield.

Nemoto, T. (2002). The Successful Handling of the Financial Crisis. In: Curtis, G.L. (ed.): Policymaking in Japan. Defining the Role of Politicians. Tokyo: Japan Center for International Exchange, 18-41.

Noble, G. W., \& Ravenhill, J. (2000). "The Asian Financial Crisis and the Architecture of Global Finance." Cambridge: Cambridge University Press.

Ocampo, J.A. (2006). Regional financial cooperation: Experiences and challenges. In J.A. Ocampo (Ed.), Regional financial cooperation. Washington, DC: Brookings Institution Press, p. 1-39.

Ocampo, J.A. (2017). Resetting the International Monetary (Non)System. Oxford: Oxford University Press.

Olson, M. (1971). The logic of collective actions: Public goods and the theory of groups. Cambridge, MA: Harvard University Press.

Park, Y. C.; \& Wang, Y. (2002). What kind of international financial architecture for an integrated world economy? Asian Economic Papers, 1(1), 91-128.

Park, Y. C., \& Wyplosz, C. (2010). Monetary and Financial Integration in East Asia. The Relevance of European Experience. Oxford: Oxford University Press.

Park, Y.C. (2006). Economic Liberalization and Integration in East Asia: A Post-Crisis Paradigm. Oxford University Press. 
Park, Y.C. (2011). The Global Financial Crisis: Decoupling of East Asia - Myth or Reality? ADBI Working Paper Series, No. 289.

Pearson, M. (2005). The Business of Governing Business in China: Institutions and Norms of the Emerging Regulatory State. World Politics, 57 (2), 296-322.

Pekkanen, S. (2013). Asian Designs: Risen Powers and the Struggle for International Governance. Manuscript, University of Washington, Seattle.

Pelisson, D. (2015). Os Programas de Ajuste do FMI: condicionalidade, compliance e efeitos: uma análise dos Programas aplicados à Indonésia, Coreia e Tailândia no contexto da crise financeira asiática. Master's Dissertation. Instituto de Relações Internacionais, Universidade de São Paulo.

Pelisson, D. (2018). Alternativas regionais para administração e prevenção de futuras crises financeiras internacionais: a experiência asiática. Conjuntura Internacional. v.15 n.2, p.51 - 60, ago.

Peng, D. (2002). Invisible linkages: A regional perspective of East Asian political economy. International Studies Quarterly, 46, 423-447.

Pevehouse, J., Nordstrom, T., \& Warnke, K. (2004). The correlates of War 2: International governmental organizations data version 2.0. Conflict Management and Peace Science, 21(2), 101-119.

Pitakdumrongkit, K. (2015). Co-chairing international negotiations: the case of the Chiang Mai initiative multilateralization, The Pacific Review, 28:4, 577-605.

Prasad, E. S. (2017). Gaining Currency: The Rise of the Renminbi, New York: Oxford University Press.

Priewe, J. (2007). Reconsidering the Theories of Optimum Currency Area - a Critique. In Hein, Eckhard, Priewe, Jan and Truger, Achim (eds), European Integration in Crisis. Marburg: Metropolis, 27-52.

Putnam, R. (1988). Diplomacy and domestic politics: the logic of two-level games. International Organization, Vol. 42, No. 1.

Radelet, S. \& Sachs, J. (1998). The Onset of East Asian Financial Crisis. NBER Working Paper Series, \#6680.

Rathus, J. (2010). Japan's early moves on the East Asian community. East Asia Forum 21 March. http://www.eastasiaforum.org/2010/03/21/japans-early-moves-on-the-east-asiancommunity/.

Ravenhill, J. (2008). Trading Out of the Crisis. In MacIntyre, Andrew, T.J. Pempel, and John Ravenhill (eds.), Crisis as Catalyst: Asia's Dynamic Political Economy. Ithaca: Cornell University Press, 140-163. 
Ravenhill, J. (2010). The 'New East Asian Regionalism: A Political Domino Effect. Review of International Political Economy 17(2): 178-208.

Rohlfing, I. (2012). Case Studies and Causal Inference: an Integrative Framework, Palgrave Macmillan.

Rose, A. K., \& Stanley, T. D. (2005). A meta-analysis of the effect of common currencies on international trade. Working Paper No. 10373. Cambridge, MA: NBER.

Rosenau, J. N. (1966). Pre-theories and Theories of Foreign Policy. In Approaches in Comparative and International Politics, edited by R. B. Farrell, pp. 115-169. Evanston: Northwestern University Press.

Rüland, J. (2000) ASEAN and the Asian crisis: theoretical implications and practical consequences for Southeast Asian regionalism. The Pacific Review, 13:3, 421-451

Saez, L. (2003). Banking Reform in India and China. London: Palgrave Macmillan.

Saitô, S. (1996). Rebuilding a Bankrupt Financial Regulatory System. Japan Echo, 23, Summer 1996, 15-20.

Sakakibara, E. (1999). Reform of the International Financial Architecture - Main Elements of the G-7 Report on the Architecture. Speech by Dr. Eisuke Sakakibara Vice Minister for International Affairs Ministry of Finance, at the Symposium on Building the Financial System of the 21st Century Kyoto, Japan, (June 25th, 1999).

Sakakibara, E. (2000). Vice Minister's Speech on the Future International Financial Architecture and Regional Capital Market Development at the Round Table on Capital Market Reform in Asia in Tokyo, 11 April, 2000.

Sakakibara, E. (2003). Asian Cooperation and the End of Pax Americana. In Jan Joost Teunissen and Mark Teunissen (eds), Financial Stability and Growth in Emerging Economies: The Role of the Financial Sector. The Hague: Fondad.

Schelkle, W. (2001). Monetäre Integration: Bestandsaufnahme und Weiterentwicklung der neueren Theorie. Springer-Verlag Berlin Heidelberg GmbH.

Seawright, J.; \& Gerring, J. (2008). Case Selection Techniques in Case Study Research: A Menu of Qualitative and Quantitative Options. Political Research Quarterly, Volume: 61 Issue: 2, page(s): 294-308.

Shen, L. (2006). Banking reform speeds up in 2005, from separate operations to mixed operations. Securities Daily, December 31.

Shih, V. (2004). Dealing with Non-performing Loans: Political Constraints and Financial Policies in China. China Quarterly 180: 922-44.

Shih, V. (2007). Partial Reform Equilibrium, Chinese Style: Political Incentives and Reform Stagnation in Chinese Financial Policies. Comparative Political Studies, 40 (10), 1238-62. 
Shih, V. (2008). Factions and Finance in China: Elite Conflict and Inflation. Cambridge MA: Cambridge University Press.

Shirk, S. (1993). The Political Logic of Economic Reform in China. Berkeley: University of California Press.

Shirk, S. (1996). Internationalization and China's Economic Reforms. In Robert O. Keohane and Helen V. Milner (eds), Internationalization and Domestic Politics, 186-2016. Cambridge: Cambridge University Press.

Siregar, R. Y. \& Chabchitrchaidol, A. (2013). Enhancing the effectiveness of CMIM and AMRO: selected immediate challenges and tasks. Working Paper Series 403. Tokyo: Asian Development Bank Institute.

Slaughter, A. (2004). A New World Order. Princeton, NJ: Princeton University Press.

Smith, S.; Hadfield, A.; Dunne, T. (2008). Foreign Policy Theories, Actors and Cases. Oxford University Press.

Snyder, R. C.; H. W. Bruck; B. Sapin. (1954). Decision-Making as an Approach to the Study of International Politics. Foreign Policy Analysis Project Series No. 3. Princeton, NJ: Princeton University Press.

Snyder, R. C.; H. W. Bruck; B. Sapin, eds. (1962). Foreign Policy Decision-Making: An Approach to the Study of International Politics. Glencoe, IL: Free Press.

Solingen, E. (2008). The Genesis, Design and Effects of Regional Institutions: Lessons from East Asia and the Middle East. International Studies Quarterly 52, 261-294.

Stone, R. (2011). Controlling Institutions: International Organizations and the Global Economy. Cambridge, UK: Cambridge University Press.

Stone, R. (2013). Informal governance in international organizations: Introduction to the Special Issue Review of International Organizations.

Stubbs, R. (1995). Asia-Pacific Regionalization and the Global Economy: A Third Form of Capitalism? Asian Survey 35(9): 785-97.

Stubbs, R. (2002). ASEAN Plus Three: Emerging East Asian Regionalism. Asian Survey 42 (3): $440-55$.

Subacchi, P. (2016). The People's Money: How China is Building a Global Currency. New York: Columbia University Press.

Sun, Jie. (2007). Ways to deepen Asian financial cooperation: Japan's role and influence. World Economy and Politics 5: 59-66.

Sussangkarn, C. (2010). The Chiang Mai Initiative Multilateralization: Origin, Development and Outlook. ADBI Working Paper Series. 
Suzuki, Yu. (1996). Independent BOJ debated. Japan Times, 26 August 1996.

Takahashi, T. (1997). The New Bank of Japan Law - Moving Toward Greater Central Bank Independence. NLI Research Institute.

SWIFT (2018). RMB Tracker. January. Available at: https://www.swift.com/oursolutions/compliance-and-shared-services/business-intelligence/renminbi/rmb-

tracker/document-centre?tl=en\#topic-tabs-menu.

SWIFT (2019). RMB Tracker. September. Available at: https://www.swift.com/oursolutions/compliance-and-shared-services/business-intelligence/renminbi/rmb-

tracker/document-centre?tl=en\#topic-tabs-menu.

Tan, S. S. (2011). Is Asia Pacific regionalism outgrowing ASEAN? RUSI Journal, 156 (1), 5862.

Telò, M. (2013). Introduction: Globalization, new regionalism and the role of the European Union. In M. Telò (Ed.), European Union and new regionalism: Regional actors and global governance in a post-hegemonic era. Farnham: Ashgate, p. 1-21.

The Central Bank Study Group (1996). Reform of the Central Bank System - In Pursuit of Open Independence, 12 November 1996. Available at: http://www.kantei.go.jp/jp/singi/cyugin/hokokusyo.html.

UNCTAD (2007). Trade and development report: Regional cooperation for development. New York, NY: United Nations.

UNCTAD (2015). Trade and Development Report: Making the International Financial Architecture Work for Development. Geneva: United Nations Conference on Trade and Development.

Vabulas, F., \& Snidal, D. (2013). Organization without delegation: Informal intergovernmental organizations (IIGOs) and the spectrum of intergovernmental arrangements. Rev Int Organ 8:193-220.

Vaubel, R. (2006). Principal-Agent Problems in International Organizations. Review of International Organizations 1: 125-38.

Volz, U.; \& Fujimura, M. (2008). The Political Economy of Japanese Monetary and Exchange Rate Policy-With Special Reference to Regional Monetary Co-operation in East Asia', Institute of Economic Research Working Paper Series, 1.

Volz U. (2014). All Politics Is Local: The Renminbi's Prospects as a Future Global Currency. In: Armijo L.E., Katada S.N. (eds) The Financial Statecraft of Emerging Powers. International Political Economy Series. Palgrave Macmillan, London.

Volz, U. (2016). Toward the Development of a Global Financial Safety Net or a Segmentation of the Global Financial Architecture? Emerging Markets Finance \& Trade 52(10): 2221-37. 
Wade, R. (1998). The Asian Debt-and-development Crisis of 1997? Causes and Consequences. World Development Vol. 26(8): 1535-1553.

Walter, C. E.; \& Howie, F. J.T. (2011). Red Capitalism: The Fragile Financial Foundation of China's Extraordinary Rise. Singapore: Wiley.

Waltz, K. (1979). Theory of International Politics, Reading, MA: Addison-Wesley.

Webber, D. (2001). Two Funerals and a Wedding? The Ups and Downs of Regionalism in East Asia and Asia-Pacific after the Asian Crisis. The Pacific Review 14(3): 339-372.

Wenlei, D. (2010). Pooling Resources, Beijing Review, April 17.

Xiang, H. C. (1999). Statement by the Hon. Xiang Huaicheng, Governor of the Fund for the People's Republic of China at the Joint Annual Discussion, 28 September.

Xiao, Qi. (2006). Capital account liberalization and financial security. Finance Education and Studies 3: pp. 11-13.

Xiaoling, W. (2007). Remarks of Deputy Governor Wu Xiaoling on the International Seminar on the Tenth Anniversary of Asian Financial Crisis, 07/31/2007.

Xie, P. (1995). The Independence of the Chinese Central Bank. Shanghai Securities Daily, 5 April.

Y. Wu. (2006). The RMB Exchange Rate and Monetary Sterilization in China. China: An International Journal 4(1): 32-59.

Yam, J. (1999). Causes of and Solutions to the Recent Financial Turmoil in the Asian Region. Paper presented at the Symposium in Commemoration of Fifty Years of Central Banking in the Philippines, Banko Sentral Ng Pilipinas, Manila.

Yang, D. (2004). Remaking the Chinese Leviathan: Market Transition and the Politics of Governance in China. Stanford CA: Stanford University Press.

Ye, M. (2012). The Rise of China and East Asian Regionalism”, in Beeson, M. and Stubbs, R. (eds) Routledge Handbook of Asian Regionalism, Abingdon and New York: Routledge, 251262.

Yeung, H. W. (2009). The rise of East Asia: an emerging challenge to the study of international political economy. In Mark Blyth (ed), Routledge Handbook of International Political Economy. Routledge, p. 201-2015.

Yongding, Y.; \& Gao, H. (2011). The Internationalization of the RMB. In Y. Cheung and G. Ma (eds) Asia and China in the Global Economy, pp. 191-218. Singapore: World Scientific.

Zemin, J. (2002). Full Text of Jiang Zemin's Report at the 16th National Congress of the Communist Party of China, Beijing, November 8-14, 2002. 
Zhang, Z., Sato, K., \& McAlee, M. (2001). Is East Asia an Optimum Currency Area? Working Paper 2001-37. Kitakyushu: International Centre for the Study of East Asian Development.

Zhang, M. (2009). China's New International Financial Strategy amid the Global Financial Crisis. China and World Economy, 17:5, (September-October), pp. 22-35.

Zhao, S. (2011). China's Approaches toward Regional Cooperation in East Asia: Motivations and Calculations. Journal of Contemporary China, 20(68): 53-67.

Zhu, R. (1999). Speech by Premier Zhu Rongji of the People's Republic of China at the Third ASEAN+3 Informal Summit 28 November 1999.

Zhu, R. (2013). Zhu Rongji on the Record: The Road to Reform: 1991-1997, Washington, DC: Brookings Institution Press.

Zweig, D. (2002). Internationalizing China Domestic Interests and Global Linkages. Ithaca, NY: Cornell University Press.

\section{ASEAN Documents:}

The following documents are available at: https://asean.org

- Memorandum of Understanding on the ASEAN Swap Arrangements, 5 August 1977.

- Memorandum of Understanding on the ASEAN Swap Arrangements, 17 November 2005.

- Joint Ministerial Statement of the 3rd ASEAN Finance Ministers Meeting Ha Noi, Viet Nam, 20 March 1999

- Joint Ministerial Statement of the 4th ASEAN Finance Ministers Meeting 25-26 March 2000, Bandar Seri Begawan, Brunei Darussalam.

\section{ASEAN+3 Documents:}

The following documents are available at:

http://warp.ndl.go.jp/info:ndljp/pid/11194366/www.mof.go.jp/english/international policy/co nvention/asean_plus_3/index.htm

or

https://www.amro-asia.org/about-amro/amro-and-the-cmim/

- Chairman's Statement of the First ASEAN + China, Japan, Korea (ASEAN+3) Deputy Finance Ministers and Deputy Central Bank Governors Meeting, Ha Noi, Viet Nam, 18 March 1999. 
- $\quad 3^{\text {rd }}$ Summit of ASEAN+3, 28 November 1999.

- AFMM+3 Joint Ministerial Statement, 06 May 2000.

- AFMM+3 Joint Ministerial Statements, 09 May 2001.

- $6^{\text {th }}$ ASEAN+3 Summit, November 2002.

- AFMM+3 Joint Ministerial Statements, 10 May 2002.

- AFMM+3 Joint Ministerial Statements, 07 August 2003.

- AFMM+3 Joint Ministerial Statements, 15 May 2004.

- AFMM+3 Joint Ministerial Statement, 04 May 2005.

- AFMM+3 Joint Ministerial Statements, 04 May 2006.

- AFMM+3 Joint Ministerial Statement, 05 May 2007.

- AFMM+3 Joint Ministerial Statement, 20 June 2008.

- AFMM+3 Joint Ministerial Statement, 03 May 2009.

- AFMM+3 Joint Ministerial Statement, 02 May 2010.

- AFMM+3 Joint Ministerial Statement, 04 May 2011.

- AFMGM+3 Joint Ministerial Statement, 03 May 2012.

- AFMGM+3 Joint Ministerial Statement, 03 May 2013.

- AFMGM+3 Joint Ministerial Statement, 03 May 2014.

- AFCDM+3 meeting in Nay Pyi Taw, Myanmar, April 2014.

- AFMGM+3 Joint Ministerial Statement, 03 May 2015.

- AFMGM+3 Joint Ministerial Statement, 03 May 2016.

- AFMGM+3 Joint Ministerial Statement, 05 May 2017.

- AFMGM+3 Joint Ministerial Statement, 04 May 2018.

- AFMGM+3 Joint Ministerial Statement, 02 May 2019. 
The following documents are available at: http://www.dof.gov.ph/asean2017/

- AMRO Director's Members' Assessment, ASEAN+3 Finance Minister and Central Bank Deputies' Meeting, Cebu, 5-6 April 2017.

- AMRO Executive Committee’s Meeting, 5 April 2017, Cebu, The Philippines.

- EC 2016-6-12/11, AMRO Executive Committee's Meeting, 5 April 2017, Cebu, The Philippines.

- Co-Chairs' Summary of the ASEAN+3 Taskforce (TF) Meeting Tokyo, Japan, 24-25 January 2017.

- ERPD Matrix Report to the ASEAN+3 Deputies, AMRO Report to the ASEAN+3 Deputies, 24 March, 2017.

- Interim Report from the WG2 for the CMIM Periodic Review, 17 March, 2017.

- Operational Guidelines for CMIM Swap Transaction Mechanism, ASEAN+3 Taskforce on CMI-Multilateralization Progress Report to the AFCDM+3, Cebu, the Philippines, 5-6 April 2017.

- ASEAN+3 Taskforce on CMI-Multilateralization Progress Report to the AFCDM+3, Cebu, the Philippines, 5-6 April 2017.

ASEAN+3 Research Group's Studies available at: https://asean.org/?static_post=externalrelations-asean-3-asean3-research-group-studies

- Summary Report of Studies on 'Economic Surveillance and Policy Dialogue in East Asia'- Institute for International Monetary Affairs, Japan, 10 March 2005.

- IIMA, 2005. 'Research Papers and Policy Recommendations on Economic Surveillance and Policy Dialogue in East Asia'.

- Tadahiro, A, 2005. 'Chiang Mai Initiative as the Foundation of Financial Stability in East Asia'.

- He Fan, Zhang Bin \& Zhang Ming. (2005). 'After the CMI: The Future of Asian Monetary Cooperation and China's Role'. Institute of World Economics and Politics, Chinese Academy of Social Sciences.

AMRO Agreement. Available at: https://amro-asia.org/wp-content/uploads/2016/09/amroagreement.pdf

AMRO Annual Report, 2018. Available at: https://www.amro-asia.org/publications/corporatedocuments/amro-annual-report/

\section{IMF Documents:}


IMF Articles of Agreement.

IMF Annual Report 1999.

IMF Annual Report 2001.

IMF Annual Report 2018.

IMF, 2001, "Structural Conditionality in IMF-Supported Programs," (February), available at http://www.imf.org/external/np/pdr/cond/2001/eng/struct/index.htm.

IMF Policy Paper. (2017). Collaboration Between Regional Financing Arrangements and the IMF-Background Paper, July 31, 2017. Available at https://www.imf.org/en/Publications/Policy-Papers/Issues/2017/07/31/pp073117collaboration-between-regional-financing-arrangements-and-the-imf.

Selected Decisions and Selected Documents of the International Monetary Fund Thirty-Ninth Issue Washington, Dc March 31, 2017. Available at: https://www.imf.org/external/SelectedDecisions/DecisionsList.aspx

- Decision No. 15420-13/61 and amendments.

- Decision No. 270-53/95 and amendments.

- Decision No. 13183-04/10 and amendments.

- Executive Board Meeting 11/112, November 21, 2011.

- Interim Guidance Note of September 2000.

IMF Factsheet, February 25, 2019: https://www.imf.org/en/About/Factsheets/IMF-Lending/ Accessed on 9 October 2019.

IMF Factsheet, March 2019: https://www.imf.org/en/About/Factsheets/Sheets/2016/07/27/15/45/Standards-for-DataDissemination. Accessed on 21 October 2019.

IMF Policy Paper - Adequacy of The Global Financial Safety Net - Review of The Flexible Credit Line and Precautionary and Liquidity Line, and Proposals for Toolkit Reform Revised Proposals, 2017: file:///Users/dr/Downloads/pp121917-adequacyofgfsnrevisedproposals.pdf. Accessed on 14 October 2019.

IMF Press Release 10/418: https://www.imf.org/en/News/Articles/2015/09/14/01/49/pr10418. Accessed on 9 October 2019.

\section{Japan's Documents: Bank of Japan and Ministry of Finance}

1997 BOJ Act. Available at: http://www.cas.go.jp/jp/seisaku/hourei/data/boja.pdf.

BOJ, 2000. Basic Guidelines for the Management of External Assets Held by Bank of Japan, April 18, 2000.

Available at: https://www.boj.or.jp/en/announcements/release_2000/un0004a.htm/. 
BOJ, 2011. Functions and Operations of the Bank of Japan prepared by the Institute for Monetary and Economic Studies of Bank of Japan, January 2011. Available at: https://www.boj.or.jp/en/about/outline/data/fobojall.pdf.

BOJ, 2012. Revisions to the Management of Foreign Currency Assets, May 11, 2012. Available at: https://www.boj.or.jp/en/announcements/release_2012/rel120511b.pdf.

BOJ Annual Review Reports from 2005 to 2018. Available at: https://www.boj.or.jp/en/about/activities/act/index.htm/.

MOF, 1998. Towards a New International Financial Architecture, Speech by Mr. Kiichi Miyazawa, the Minister of Finance, at the Foreign Correspondents Club of Japan, December $15,1998$.

MOF, 1999. Reform of the International Financial Architecture Main Elements of the G-7 Report on the Architecture, Speech by Dr. Eisuke Sakakibara Vice Minister for International Affairs Ministry of Finance at the Symposium on Building the Financial System of the 21st Century Kyoto, Japan, (June 25th, 1999).

MOF, 2000. Vice Minister's Speech on the Future International Financial Architecture and Regional Capital Market Development at the Round Table on Capital Market Reform in Asia in Tokyo, April 11, 2000.

MOF, 2000. Press Statement Meeting between Minister Tarrin and Minister Miyazawa, Fukuoka, July 7, 2000.

MOF, 2005. Guidelines for the Management of Foreign Assets held in the Foreign Exchange Fund Special Account, April 4, 2005.

MOF, 2005. Press Release, November 30, 2005.

MOF, 2006. Press Release First Japan-Korea Finance Dialogue, February 4, 2006.

MOF Policy Evaluation Reports from 2013 to 2017.

\section{China's Documents: People's Bank of China and SAFE}

2003 PBC Law.

Available at: http://www.pbc.gov.cn/en/3688253/3689003/3709953/index.html.

PBC, 1999. Press Release - Address by Premier Zhu Rongji of the People's Republic of China at the Third ASEAN+3 Informal Summit 28 November 1999.

PBC, 2001. Press Release - The Central Banks of China and Thailand Signed Currency Swap Agreement, 06/12/2001.

PBC, 2002. Press Release - China's Financial Opening-Up and Financial Cooperation in Asia, 04/15/2002. 
People's Bank of China Study Group. (2006). 'The Timing, Path, and Strategies of RMB Internationalization', China Finance, 5, pp. 12-13.

PBC, 2007. Press Release - Remarks of Deputy Governor Wu Xiaoling on the International Seminar on the Tenth Anniversary of Asian Financial Crisis, 07/31/2007.

PBC, 2008. Press Release - Senior Official of the PBC Interviewed for PBC-BOK Currency Swap Agreement, 12/12/2008.

PBC, 2009. Press Release - Strengthen Regional Financial Cooperation and Actively Conduct Currency Swap, 03/31/2009.

PBC, 2013. Press Release - Deepening Bilateral and Regional Financial Cooperation to Promote Sustainable Development in the Region, Speech by Deputy Governor Yi Gang at 5th China-ASEAN Summit Forum on Financial Cooperation and Development, Nanning, Guangxi, September 4, 2013.

PBC, 2013. Press Release - Governor Zhou Xiaochuan Attended BRICS Finance Ministers and Central Bank Governors’ Meeting, 04/01/2013.

PBC, 2014. Press Release - Annual Seminar for PBC Branch Office Presidents Concluded, 08/08/2014.

PBC, 2016. Transcript of Governor Zhou Xiaochuan's Press Conference, 03/10/2016; Transcript of Governor Zhou Xiaochuan's Exclusive Interview with Caixin Weekly, 02/14/2016.

PBC, 2017. Governor Zhou Xiaochuan Answered Press Questions at the 19th National Congress of the Communist Party of China, 10/20/2017.

PBC, 2017. Prospects of the Chinese Economy: Broad-Based Growth, Governor Zhou Xiaochuan's Speech and Q\&A at the 32rd G30 Annual International Banking Seminar, 10/16/2017.

PBC RMB Internationalization Report, 2017.

Available at: http://www.pbc.gov.cn/en/3688241/3688636/3828468/index.html

PBC Annual Reports, from 2013 to 2017.

Available at: http://www.pbc.gov.cn/en/3688259/index.html.

PBC, 2017. A non-paper on making contribution to CMIM in local currencies, March 1, 2017.

PBC, 2018. PBC Governor Zhou Xiaochuan and Two Deputy Governors Answered Press Questions on Financial Reform and Development, 03/22/2018.

SAFE, 2010. FAQs on Foreign Exchange Management Policies, 02/07/2010.

SAFE, 2011. FAQs on Foreign Exchange Reserves, 07/20/2011. 


\section{Other Documents:}

CRA Agreement. Available at: http://www.brics.utoronto.ca/docs/140715-treaty.html. 